DOI: 10.1590/permusi2015a3114

\title{
O potencial musical de Belo Horizonte como motor de uma estratégia de desenvolvimento local ${ }^{1}$
}

\author{
Jane Maria De Medeiros (UNA, Belo Horizonte, MG) \\ janemed05@yahoo.com.br
}

Lucília Regina de Souza Machado (UNA, Belo Horizonte, MG)

lucilia.machado@una.br

\begin{abstract}
Resumo: O cenário musical de Belo Horizonte, capital do estado de Minas Gerais, apresenta uma produção caracterizada por grande riqueza, qualidade criativa, inovações e crescente dinamismo. Tais ingredientes seriam suficientes para se pensar na possibilidade da construção de um Sistema Produtivo e Inovativo Local (SPIL) da música dessa cidade? Tal indagação motivou a discussão sobre as condições existentes ou as que precisariam ser criadas para que este sistema pudesse ser organizado. Nesse sentido, foram analisados os fatores que poderiam facilitar ou impedir essa construção. Palavras-chave: sistemas produtivos e inovativos locais; inovação e música; economia da cultura; gestão social; desenvolvimento local.
\end{abstract}

\section{Belo Horizonte's musical potential as the driving force for local development}

\begin{abstract}
The music scene in the city of Belo Horizonte, capital of Minas Gerais, Brazil, has its production characterized by great diversity, creative quality, innovation and growing dynamism. Would these ingredients be sufficient to consider the possibility of building a Local Production and Innovation System (SPIL by short) of music in this city? This question led to a discussion about the existing conditions or those that need to be created so that this system could be organized. Accordingly, we analyzed the factors that may facilitate or prevent such construction.

Keywords: local production and innovation systems; innovation and music; culture economy; social management; local development.

\section{1 - Introdução}

Centro geográfico do Brasil, fazendo fronteira com outros seis Estados², Minas Gerais é constantemente apontada como um estado de grande diversidade cultural. Segundo o escritor João Guimarães Rosa, "seu orbe é uma pequena síntese, uma encruzilhada; pois Minas são muitas. São, pelo menos, várias Minas...". WERKEMA (2010, p.95) vai mais além, considerando que, no Estado,

... em qualquer direção, uma distância de 100 quilômetros representa mudança cultural, com alterações locais relativas ao patrimônio histórico e natural, como igualmente nos hábitos, nas festas populares e religiosas, na culinária e no artesanato. E ainda bastante singularidade, exemplaridade e, especialmente, autenticidade e originalidade nesses elementos. Eis a riqueza de Minas.
\end{abstract}

Planejada para ser a capital do estado, Belo Horizonte nasce da união de esforços de mineiros de todo o interior, gente de todas as partes do país e imigrantes estrangeiros, que buscam empregos, melhores oportunidades de vida e, sobretudo, a modernidade (CASTRO, 1997). Essa mistura teria sido o fator mais importante para que a capital se tornasse uma síntese das manifestações culturais do estado, refletindo toda a sua diversidade e criatividade.

Segundo WERKEMA (2010), essa característica de atrair o interior sempre esteve presente na história da capital mineira refletindo-se de forma ainda mais marcante no segmento musical. Como polo econômico e cultural, a ela se dirigem os artistas que 
querem desenvolver uma carreira, tornando-a uma caixa de ressonância da produção mineira. Bruno MARTINS (2009), ao analisar a origem do movimento musical mineiro Clube da Esquina, nascido em Belo Horizonte, afirma que seus integrantes, além de trazerem para a capital influências musicais, também trouxeram um pouco da sua cidade natal, a partir de "suas referências históricas e culturais particulares". O autor considera que isso "fez da capital mineira um solo aglutinador, em torno do qual as cidades de onde partiram tais viajantes se avizinhavam pelos caminhos da canção". (MARTINS, 2009, p.46)

Embora ainda pouco estudada ${ }^{3}$, a área cultural mineira, em especial a de Belo Horizonte, tem recebido frequentes e importantes registros na mídia nacional e internacional destacando essas características e apontando o sucesso de diversos atores de diferentes segmentos. Esse quadro seria característico de um universo cultural rico, diversificado, dinâmico e, principalmente, inovador, que deixaria marcas relevantes na identidade, não apenas da cidade, mas do Estado.

Tais informações dão conta de experiências bem-sucedidas em praticamente todos os segmentos culturais - das Artes Plásticas à Dança, do Teatro ao Audiovisual -, passando destacadamente pela Música. Dentre as mais citadas, as experiências dos grupos de teatro Galpão e Giramundo; Grupo Corpo e $1^{\circ}$ Ato, na dança; artistas plásticos como Yara Tupinambá e Amílcar de Castro; profissionais do audiovisual, como Helvécio Ratton (de longas-metragens), Cao Guimarães (de curtas-metragens e também artista plástico expositor no MOMA, em Nova lorque) além do videomaker Éder Santos, entre muitos outros.

Ao analisar a turnê mundial do Grupo de Dança Corpo em 2006, o jornal The Globe and Mail da capital do Canadá, Ottawa, confirma essa visão:

Durante 30 anos a companhia tem sido o principal embaixador cultural da dança
contemporânea do Brasil por aqui e é um prazer dizer que eles voltaram com
estilo ao melhor de sua forma. Os dois trabalhos apresentados, Lecuona (2004) e
Onqotô (2005), não são apenas uma demonstração da fantástica qualidade dos
seus dançarinos, que poderiam plausivelmente ser considerados dos melhores
do planeta; eles são também a prova de que Rodrigo Pederneiras encontrou
novas inspirações para o seu trabalho de coreógrafo ${ }^{4}$.

$\mathrm{Na}$ área da Música, as informações em circulação apontam para uma riqueza e uma diversidade da produção cultural belo-horizontina ainda mais palpáveis. Da MPB ao heavy metal, passando pela música instrumental, o pop-rock e até a música eletrônica. Essas manifestações teriam produzido importantes representantes da cidade no circuito nacional e internacional: o Clube da Esquina - movimento que revelou Milton Nascimento, Fernando Brant, Beto Guedes, Lô Borges, entre outros e é tido como um marco revolucionário da história da música mineira e brasileira (MARTINS, 2009) -; o ícone do heavy metal Sepultura considerado o grupo brasileiro de maior repercussão no mundo; a banda Skank, que além de vender milhões de discos no Brasil, chegou a liderar as paradas de sucesso na Espanha em 1996; o Pato $\mathrm{Fu}$, banda de rock alternativo, reconhecida nacional e internacionalmente, entre muitos outros.

Cantores e instrumentistas que desenvolvem carreira solo também estariam se destacando no cenário nacional e internacional. É o caso do multi-instrumentista, compositor, arranjador e regente Maurício Tizumba ${ }^{5}$ e do baterista Dedé Sampaio, que 
deixou uma família de sete irmãos - dos quais seis se tornaram bateristas - no bairro Caiçara para fazer sucesso nos Estados Unidos, tendo tocado, inclusive, com o ícone do jazz americano Miles Davis. Até na música erudita Belo Horizonte teria produzido destaques nacionais, como Sebastião Vianna (pianista, flautista, acordeonista, assistente de Villa Lobos) e seu filho, Marcus Viana.

A efervescência desse gênero na cidade teria levado ao surgimento da Orquestra Filarmônica de Minas Gerais em 2008, para atuar ao lado da tradicional Orquestra Sinfônica do Estado de Minas Gerais ${ }^{6}$ e da Orquestra de Câmara Sesiminas ${ }^{7}$. Belo Horizonte também estaria sendo reconhecida como um dos principais centros produtores de ópera do país, a partir do trabalho desenvolvido na última década pela Fundação Clóvis Salgado ${ }^{8}$. Essa opinião é compartilhada pelo diretor e produtor Cleber Papa, que transita pelos principais centros de música clássica do país e do exterior:

São Paulo e Rio de Janeiro estão passando por reformas, Brasília não avançou. Porto Alegre não produz nada de consistente e o Festival Amazonas está em franca decadência. O Palácio das Artes está entre os poucos que fazem ópera com qualidade no Brasil e isto não pode ser visto com timidez. Existe potencial e reserva técnica para Minas se tornar uma referência internacional ${ }^{9}$.

Além da quantidade e da qualidade da produção musical belo-horizontina, o dinamismo na área, não apenas no que diz respeito ao surgimento de novos instrumentistas, cantores e grupos, mas também nos quesitos produção e gestão, seria característica de grande criatividade e inovação. Exemplos recentes: o BH Indie Music - festival de bandas alternativas, surgido em 2008 com o objetivo de criar vitrine mineira para a música alternativa e a Festa da Música (inspirada na Fête de la Musique, realizada na França há 29 anos), criada em 1997. Durante dez dias, este projeto, que é anual, apresenta shows de música instrumental (destaque para o jazz) em parques, praças, ruas e teatros da capital, abertos ao público.

Na área da gestão, exemplos consistentes seriam a criação, em 2007, em Belo Horizonte, da primeira Cooperativa de Trabalho dos Profissionais de Música do Estado de Minas Gerais (Comum) e a organização, no final de 2008, do Fórum da Música de Minas Gerais. Além da Comum, este fórum reúne representantes da Associação Artística dos Músicos de Minas Gerais (AMMIG), da Associação dos Amigos do Museu Clube da Esquina (AAMUCE), da Sociedade Independente da Música (SIM) e do Fora do Eixo Minas, todos com sede e atuação direta na capital. Contando com a participação do Serviço Brasileiro de Apoio às Micro e Pequenas Empresas (SEBRAE) ${ }^{10}$ nas discussões para sua criação, 0 Fórum surgiu com a missão principal de gerir o Música Minas, em parceria com o Governo do Estado - programa, até então inédito, de disseminação e exportação da música mineira.

No que diz respeito à inovação, são muitos os exemplos significativos. Um dos mais recentes seria a atuação criativa do DJ (disc jockey) belo-horizontino, conhecido mundialmente, Anderson Noise, que realizou projeto inédito no Brasil de executar solo nos pick-ups e nos teclados, introduzindo a música eletrônica em um concerto de música erudita. Ele se apresentou em 2009 com a Orquestra Bachiana Filarmônica de São Paulo, regida pelo consagrado maestro João Carlos Martins. Outro exemplo: os instrumentos inovadores e a linguagem musical variada que tornaram o grupo belo-horizontino Uakti ${ }^{11}$ 
uma das referências mais fortes da música contemporânea mundial, além de um marco na história da música mineira, a partir da década de 1980. O compositor Marcus Viana também teria sido pioneiro ao escrever uma trilha sonora inteira para uma novela televisiva (Pantanal, 1990) e ao eletrificar o violino em Minas Gerais.

Apesar da contundência das informações a respeito da qualidade criativa e inovativa e do dinamismo do setor musical da capital mineira, existiria uma possível lacuna caracterizada pela ausência de políticas voltadas ao atendimento das demandas deste setor e ao incentivo de seu desenvolvimento. Nem mesmo o fato de a música ter sido considerada pelo Ministério da Cultura (MinC) um dos polos mais dinâmicos da economia da cultura no Brasil no Programa de Desenvolvimento da Economia da Cultura (Prodec), aprovado em 2006 no âmbito do Plano Plurianual do Governo Federal, teria sido suficiente para estimular a criação de políticas públicas de aproveitamento do dinamismo musical de Belo Horizonte.

Consideramos os polos mais dinâmicos da Economia da Cultura no Brasil: Música (produtos e espetáculos); Audiovisual (em especial conteúdo de tv, animação, conteúdo de Internet e jogos eletrônicos); Festas e expressões populares (onde se destacam o Carnaval, o São João, a capoeira e o artesanato). (PORTA, 2008, p.5).

O cenário exposto acima - o potencial musical de Belo Horizonte e a crescente importância da economia da cultura -, pareceu constituir-se em forte indício de que, devidamente trabalhado, poderia se transformar em importante motor de uma estratégia de desenvolvimento local.

\section{2- Metodologia e procedimentos de investigação}

A metodologia utilizada neste estudo foi elaborada a partir do ferramental de pesquisa proposto pela RedeSist ${ }^{12}$ para analisar Arranjos e Sistemas Produtivos e Inovativos Locais (ASPILs). Foram feitas modificações e adaptações consideradas necessárias a um projeto de estudo de atividades culturais, que se propõe a levar em consideração a complexa inter-relação entre forças econômicas e culturais, e entre inovação e tradição, dentro das características do espaço e da área estudados, respectivamente, o município de Belo Horizonte e a música.

Ao procurar analisar em profundidade as percepções de sujeitos, visando obter respostas sobre condições atuais e que precisam ser criadas e elementos facilitadores e inibidores do desenvolvimento de um SPIL da música, a pesquisa assumiu caráter qualitativo. Baseou-se no entendimento de que a compreensão e interpretação dessas percepções subjetivas não são isoladas, mas inseridas num contexto que sofre e provoca influências no todo. Nessa perspectiva, a pesquisa teve caráter exploratório e aplicado. Exploratório, pois não fez generalizações sobre condições de criação de SPILs. Aplicado, porque procurou sistematizar um conjunto de referências que pudessem servir à elaboração de um projeto de criação do SPIL da Música de Belo Horizonte.

Partiu-se do princípio de que estas características da investigação (qualitativa, exploratória, aplicada) pudessem contribuir para a inclusão, mobilização e articulação dos atores do segmento musical de Belo Horizonte. Foram utilizadas técnicas de pesquisa bibliográfica e documental e de documentação direta. Como em toda pesquisa qualitativa, 
aqui também o papel do pesquisador foi considerado com a devida atenção e cuidados, especialmente porque a autora atua na área em questão há alguns anos.

Visando maximizar a confiabilidade da pesquisa, utilizou-se o critério de credibilidade, apropriado por meio de procedimentos apontados por ALVES-MAZOTTI (1998, p.175). Para checar se "os resultados e interpretações feitas pelo pesquisador são plausíveis para os sujeitos envolvidos", adotou-se quatro procedimentos específicos. O primeiro deles visou garantir uma imersão maior da pesquisadora no campo, uma vez que a permanência prolongada já estava garantida. Desta forma, durante o período de estudo, a pesquisadora participou diretamente de várias atividades ligadas ao segmento musical da capital, desde seminários voltados para temas específicos, como a inserção do músico no mercado, até reuniões do Fórum da Música, passando por mobilizações públicas em defesa do Programa Música Minas.

No segundo procedimento, que buscou o "questionamento por pares", foi solicitado a colegas não envolvidos na pesquisa, mas que trabalham no mesmo paradigma e conhecem o tema pesquisado, que funcionassem como "advogados do diabo", apontando "falhas, pontos obscuros e vieses nas interpretações", bem como identificando evidências não exploradas e oferecendo "explicações ou interpretações alternativas" àquelas elaboradas pela pesquisadora. Como terceiro procedimento, realizou-se a triangulação de fontes, isto é, houve o cruzamento de informações coletadas em diferentes fontes. No último procedimento, ao final da pesquisa, solicitou-se a alguns dos participantes que fizessem a "checagem" dos resultados e conclusões obtidos para verificar se as interpretações da pesquisadora faziam sentido, a partir da avaliação quanto à sua precisão e relevância.

Definido o universo a ser pesquisado, a partir do recorte da gestão do segmento da música na cidade de Belo Horizonte, dentro do conceito de economia da cultura e na perspectiva da criação de um SPIL visando o desenvolvimento local, a população investigada envolveu 18 pessoas diretamente ligadas à produção, circulação, divulgação, pesquisa, ensino ou estudo do segmento na cidade. A pesquisa de campo se deu por meio de entrevistas semiestruturadas. A análise e a interpretação dos dados foram feitas de forma interativa com a coleta, acompanhando o processo de investigação, buscando, a partir da identificação de temas e dados, construir interpretações, gerar novas questões e aperfeiçoar questões anteriores.

\section{3 - Perspectivas e condições para a criação do SPIL da música}

Os estudos e análises realizados apontaram um quadro bastante favorável à proposta de criação de um Sistema Produtivo e Inovativo Local da Música na cidade de Belo Horizonte. Das seis características consideradas fundamentais pela REDESIST (2005) para a criação de um SPIL, a capital mineira apresentou condições satisfatórias em pelo menos quatro. No primeiro aspecto, da dimensão territorial onde ocorrem os processos produtivos, inovativos e cooperativos, o município - por sua característica de grande contingente populacional, concentrado em área relativamente reduzida e organizada em regionais - possibilita o compartilhamento de valores e visões econômicos, sociais e culturais, facilitando o dinamismo local e a diversidade. Também a sua localização central no mapa brasileiro e estrategicamente posicionada, próxima às capitas do Rio de Janeiro e São Paulo - eixo econômico e cultural do país - Ihe confere importante vantagem competitiva em relação a outros locais. 
A segunda condição positiva - fartamente comprovada pelos dados obtidos - é assegurada pela marcante diversidade de atividades e atores econômicos, políticos e sociais, que, além de recheada de empresas e associações ligadas ao segmento musical, conta com a presença de órgãos públicos (local, estadual e federal) gestores de cultura, além de uma gama enorme de organizações públicas e privadas voltadas para a formação e capacitação de recursos humanos, pesquisa, promoção e financiamento no âmbito cultural. A cidade é reconhecida como polo educacional e de pesquisa científica.

Tal diversidade de atividades se caracteriza por dar vazão a uma produção musical dinâmica, com fortes características de inovação, cuja quantidade e qualidade são amplamente reconhecidas. Ao mesmo tempo, verifica-se a presença de um processo robusto de aprendizado, que permite a aquisição e a construção de diferentes tipos de conhecimentos, competências e habilidades. Para a REDESIST (2005), aprendizado e inovação interativos - que constituem a terceira condição importante para este sistema seriam os fatores que trariam maior peso à competitividade dinâmica e sustentada de um SPIL. A pesquisa constatou que esses fatores encontram-se presentes de forma incisiva na cadeia produtiva da música de Belo Horizonte.

Não apenas os próprios atores do segmento musical da capital mineira reconhecem e se orgulham da qualidade da produção local, mas esta, quando difundida, é valorizada de forma ampla e sistemática, alcançando sucesso em diferentes praças do país e do exterior. A pesquisa constatou que esta qualidade da música tem como uma de suas bases principais o conhecimento implícito e incorporado por seus músicos - o chamado conhecimento tácito, quarta condição necessária ao SPIL -, cuja produção apresenta forte especificidade no que diz respeito ao conteúdo harmônico, passado adiante de geração em geração e caracterizado como importante elemento de vantagem competitiva da cadeia produtiva local. Este conhecimento tácito é um dos fatores responsáveis pela cidade ser considerada produtora de grandes marcas de inovação musical - como o movimento Clube da Esquina, já consolidado, e a música instrumental, de Toninho Horta $^{13}$, Nivaldo Ornelas ${ }^{14}$ e Juarez Moreira ${ }^{15}$-, resultado de um processo oriundo de múltiplas fontes e de complexas interações entre seus atores.

\subsection{Inovação}

Confirmando as análises da REDESIST (2005), segundo as quais as especificidades e trajetórias de um determinado desenvolvimento local contribuiriam para configurar um sistema de inovação característico, essa capacidade de inovação belo-horizontina é determinada por diferentes fatores sociais, políticos e econômicos. Os mais importantes seriam: as influências culturais distintas (barroca, da cultura negra, de migrantes do interior do estado, de imigrantes italianos e espanhóis - principalmente), que o produto musical recebe; a diversidade de origem, de formação e das atividades dos músicos; a reconhecida experiência, flexibilidade e capacidade de integração dos atores envolvidos no processo; a existência de processos de aprendizagem tecnológica voltados à inovação; e a existência de diversos movimentos orientados para diferentes gêneros musicais, o que gera uma música diversificada, rica, dotada de grande versatilidade.

Nessa perspectiva, deve-se levar em conta, também, a constatação feita de que Belo Horizonte possui público exigente e aberto a novas tendências, condição que impulsiona a busca pela qualidade artística e estimula as inovações. É também relevante o fato da 
capital mineira registrar a presença de uma ampla e bem informada juventude, capaz de fortalecer os atores sociais desse processo.

Outro aspecto que destaca a capital mineira no cenário nacional - considerado importante fator econômico do SPIL - é a elevada participação de seus músicos no âmbito do emprego formal da cidade (23\% acima da média nacional, segundo cálculos efetuados a partir dos dados da RAIS/MTE) ${ }^{16}$. Isto significa uma clara especialização de Belo Horizonte na atividade musical, muito além das registradas em grandes capitais brasileiras tradicionais produtoras de música, que, ao contrário, apresentam coeficiente de especialização inferior ao nacional: 29\% menor no Rio de Janeiro, 27\% menor em São Paulo e 9\% menor em Salvador.

Este índice mostra, em Belo Horizonte, a possibilidade de um peso dos atores musicais no arranjo do setor que não se observa nas outras capitais analisadas. Esta condição adquire ainda mais importância se levarmos em conta as grandes dificuldades para o exercício da profissão de músico na capital, ao contrário do que acontece no eixo Rio-São Paulo, beneficiado pela influência de grandes mídias (jornais, rádios, TVs); da presença de público com alto poder aquisitivo, aliado ao maior acesso à cultura; e da localização das majors neste eixo.

\subsection{Restrições a serem superadas}

Essa especialização, a produção efervescente e as características de inovação, no entanto, não se refletem em um mercado aquecido para o produto musical local, nem em políticas públicas de geração de trabalho e renda para o músico, obrigado a conviver com um quadro permanente de incertezas e instabilidade. Todo esse potencial também não é aproveitado como fator para impulsionar o desenvolvimento local. É nesse contexto que foram encontradas as principais restrições que precisariam ser superadas por meio da criação das condições necessárias para se chegar ao desenvolvimento do SPIL proposto.

Trata-se do necessário processo de articulações e interações, que permita alcançar a governança necessária à construção desse sistema. Como pontua a REDESIST (2005), o desafio colocado é o de encontrar diferentes modos de coordenação entre os atores e as atividades da cadeia produtiva da música de Belo Horizonte, que envolvem da produção ao consumo dos produtos musicais, assim como o processo de geração, uso e disseminação de conhecimentos e de inovações.

Nessa perspectiva, a participação organizada e direcionada das entidades representativas dos músicos precisará assumir o papel relevante de ser o ponto de partida, o estímulo para deslanchar a discussão sobre este sistema, uma vez que a pesquisa mostrou que o poder público local encontra-se alheio e, em alguns casos, completamente desconectado da realidade vivida pela cultura na cidade. Esta avaliação é corroborada pela análise feita por CARSALADE (2005, p.4), segundo a qual o afastamento do Estado de suas funções tradicionais de produtor e provedor levaria "como resposta, à necessidade imperiosa da contribuição social e de formas de gestão parceiras e participativas". Caberá, assim, aos músicos, por meio de suas entidades representativas, tomarem a frente desse processo.

O passo seguinte será atrair a participação direta e efetiva da Prefeitura, por meio da Fundação Municipal de Cultura - essencial à coordenação desse processo -, e a do Governo do Estado, por meio da Secretaria Estadual de Cultura, de forma coordenada e 
integrada ao poder local. Por outro lado, também será preciso alcançar formas de coordenação que envolvam os segmentos da indústria e do comércio - com presença forte e dinâmica na capital -, além das instituições de ensino e pesquisa.

Por sua subjetividade, a arte, em geral, e a música, em particular, exigem debates e articulações mais complexas, tornando esse processo - já difícil pelo seu caráter sistêmico e inovativo - ainda mais desafiador. A pesquisa constatou que, embora haja presença altamente significativa de atores econômicos, políticos e sociais no território estudado, estes ainda precisariam se preparar e se qualificar melhor para adquirirem as condições necessárias para integrar o SPIL. A seguir, são apresentadas as principais deficiências e dificuldades encontradas nesses segmentos e relacionados alguns instrumentos e meios para obtenção das condições necessárias à sua superação.

\subsection{Principais deficiências dos segmentos econômicos, sociais e políticos e os instrumentos e meios para obtenção das condições necessárias à sua superação}

Quanto ao segmento musical, foi detectada a necessidade de se aprofundar e fortalecer a sua organização, além da sua capacidade de articulação com os demais atores do sistema. Faz-se necessário o fomento de clima cooperativo e associativo, visando maior conscientização e participação política dos músicos nas questões de interesse da categoria, o que contribuiria para que ela participasse mais efetivamente do sistema proposto. Um fator complicador de Belo Horizonte - reflexo de característica atribuída aos mineiros em geral - é o aspecto cultural que envolve a postura tímida dos músicos locais na divulgação e defesa de seu trabalho. A mudança para um comportamento mais ousado, proativo, é um dos requisitos para qualificá-los como os principais atores desse processo.

Para isso, um passo essencial, apontado pelos dados recolhidos, é o que envolve a conscientização dos próprios músicos, a urgência de se enxergarem como uma categoria profissional, fortalecendo suas entidades representativas, tendo como foco o interesse coletivo. Embora haja sindicatos de músicos e ordem dos músicos no Brasil, o espírito gregário desta categoria profissional não encontra condições objetivas favoráveis para florescer e se fortalecer. Isso se dá, em parte, porque ao longo dos anos essas entidades se mostraram distantes dos interesses da categoria, o que levou ao seu esvaziamento e perda de qualquer traço de representatividade, provocando a pulverização dos músicos em diversas outras associações e sociedades.

Entretanto, a maior parte dos fatores que dificultam o fortalecimento desse espírito gregário está associada a contingências objetivas da trajetória de estudo e trabalho dos músicos. A formação desse profissional - o aprendizado de um instrumento ou de canto é um processo desenvolvido individualmente, levando-o a certo isolamento. Por outro lado, o exercício da profissão, de criação ou de interpretação, mesmo quando em grupo, também tem características fortemente solitárias, como confirma o músico e produtor cultural Tadeu Martins ${ }^{17}$, quando destaca que mesmo num show, que é coletivo, você tem o artista e os acompanhantes, onde esses têm um valor secundário em relação ao artista, que acaba se distinguindo dos demais.

A comparação destas particularidades com a organização e o trabalho em grupo dos artistas do teatro, feita por vários dos entrevistados pela pesquisa, dá a dimensão dos caminhos que os músicos ainda precisam percorrer. Os atores de teatro estão habituados 
a trabalhar coletivamente. Mesmo um monólogo, por exemplo, envolve vários profissionais - da preparação do texto da peça, passando pela direção, até a construção de cenários e figurinos; tudo depende do conjunto.

Ao contrário, da criação à interpretação, o músico está sempre sozinho.

Isto se reflete diretamente no comportamento profissional, social e até político de ambos os segmentos. Enquanto o ator está acostumado a compartilhar a arrecadação da bilheteria (sempre uma incógnita), como forma de remuneração de seu trabalho, o músico só valoriza o cachê, cujo valor é assegurado antes da sua apresentação. Muito recentemente, e ainda de forma tímida, têm sido realizadas experiências de apresentações musicais remuneradas pela bilheteria. Uma ação mais coletiva neste sentido foi tentada em Belo Horizonte pela Associação Artística dos Músicos de Minas Gerais (AMMIG), no final da década de 1990. A exemplo da Campanha de Popularização do Teatro, criou-se uma campanha de popularização da música - um mês de shows com participação de dezenas de artistas de todos os gêneros, do sertanejo à música erudita, sem cachê, onde a remuneração dos artistas advinha da bilheteria.

Segundo o músico e produtor Thelmo Lins ${ }^{18}$ - participante do processo - embora a adesão inicial dos músicos tenha sido grande, "a iniciativa não foi à frente porque os músicos não gostaram de não ganhar cachê" e ter de se contentar, em muitos casos, com valores pequenos oriundos da divisão da bilheteria com a produção do espetáculo. Os artistas da música não demonstram o mesmo grau e espírito de cooperação no que diz respeito ao envolvimento no processo cultural como um todo. Essa situação pode ser comprovada pela dinâmica e histórica atuação do Sindicato dos Artistas e Técnicos em Espetáculos de Diversões de Minas Gerais (Sated/MG) e do Sindicato dos Produtores de Artes Cênicas de Minas Gerais (Sinparc), que, entre outras coisas, se reflete nos inúmeros espaços conquistados para o teatro na cidade e no grande número de projetos públicos para o setor.

A reversão desse quadro, entretanto, mostrou-se viável, mas, para se tornar realidade, precisa partir da iniciativa das próprias entidades, por meio de campanhas educativas entre seus associados e também entre os músicos em geral, que resultem na ampliação da participação da categoria nas deliberações e na implementação das ações dessas organizações. Um caminho possível seria o trabalho dessas entidades junto aos estudantes das escolas de música da cidade - convidando-os a participarem de reuniões e fóruns da categoria, por exemplo -, a fim de informá-los e despertá-los para a questão, levando à construção de vínculos cada vez mais cedo com os interesses e problemas comuns.

Para que isto seja possível, no entanto, constatou-se a necessidade de que essas entidades passem por uma reformulação no sentido de se estruturarem para serem capazes de prestar os serviços demandados por seus associados. E para que isto ocorra, será preciso planejamento estratégico, plano de ação, estatuto, enfim, um arcabouço estruturante, que lhes permita conhecer as demandas reais da categoria e atuar em direção aos interesses da maioria, e não apenas aos dos grupos no exercício da direção. Isto pressupõe organização autossustentável, com cobrança de contribuição (mensalidade ou anuidade), o que hoje não acontece na maioria das entidades. É preciso criar um círculo virtuoso, onde o filiado se imponha a responsabilidade pelo desembolso financeiro para ajudar a manter a entidade, e que, em troca, tenha o retorno em prestação 
de serviços que lhe interessem; ao mesmo tempo em que a entidade se beneficia da contribuição financeira para se manter, abre-se para a participação dos filiados em todos os níveis de decisão. A profissionalização dessas entidades mostrou-se fundamental.

O outro lado dessa moeda é a necessidade de que os próprios músicos se interessem e vejam como prioritária a atuação junto aos órgãos de representação da categoria, para torná-los mais fortes e porta-vozes legítimos de seus anseios e necessidades. Embora os entrevistados tenham sido unânimes em afirmar a camaradagem existente entre os músicos da capital, não importando o gênero musical ou a origem de sua formação, os dados recolhidos pela pesquisa permitem afirmar que o sentimento de coletividade, de união em defesa dos direitos de todos, de organização e conscientização da categoria ainda está longe de poder ser generalizado, consistindo em fator que precisará ser trabalhado para se tornar favorável à construção do SPIL da música de Belo Horizonte. Como exemplifica a fala de um dos entrevistados: "o cenário da música em Minas tem muita estrela, mas elas não formam uma constelação".

A formação de uma consciência coletiva e associativa se impõe como necessidade inadiável, até mesmo para que os músicos passem a se ver como agentes sociais e políticos em condições de participar desse processo. Entidades mais representativas e filiados mais participativos formam uma coalizão fundamental para permitir que o Fórum da Música de Minas - constituído por essas entidades - ganhe a força necessária para se transformar em porta-voz do segmento musical como um todo, podendo representá-lo com legitimidade no processo de criação do SPIL. Essa é uma questão crucial, pois os músicos são os principais interessados na criação desse sistema e somente a sua mobilização, atuação organizada e direção poderão alavancar este processo.

A constituição do Fórum por meio de entidades, e não de pessoas - como é usual -, além de inovadora, pode, na prática, contribuir para a organização do segmento musical, por depender de entidades representativas e dinâmicas para a sua sobrevivência. Ficou claro, ainda, que o Fórum também precisaria passar por uma reformulação capaz de dotá-lo da infraestrutura organizacional necessária para assumir o papel de representante do conjunto do segmento. Para ser eficaz, esta reformulação deverá incluir a criação de um estatuto e dos instrumentos necessários para definir e regular a participação de seus membros. Também se faz necessário ampliar o número de membros do Fórum, atraindo entidades ligadas a outros segmentos, tais como música de viola, músicos da noite artistas que se apresentam em bares e restaurantes, música erudita, bandas de música, etc.

Este problema pode ser explicado pela própria origem do Fórum. Como ele nasceu com a responsabilidade de gerir o programa Música Minas, de exportação e disseminação da música mineira, seus integrantes logo foram sendo absorvidos pelas tarefas decorrentes do desenvolvimento do programa - pelas quais são remunerados -, faltando tempo para ações de planejamento e construção do próprio Fórum. Na avaliação de alguns dos entrevistados, o que também pode ser constatado pela pesquisa, tanto envolvimento levou a que, na prática, o Fórum se confundisse com o próprio programa, o qual, se acabar, leva a entidade consigo. Detectou-se, assim, a necessidade urgente de se pensar no conjunto, de se planejar estrategicamente a organização do Fórum, visando a sua profissionalização, de modo a contribuir para que ele conquiste as condições necessárias 
para representar o segmento nesse processo de articulação com os demais atores envolvidos no sistema proposto.

Do ponto de vista das empresas - outro segmento importante na construção do SPIL da música -, a pesquisa mostra a necessidade de se criar ações que visem sensibilizar o empresariado para a importância do investimento em cultura, não apenas para o estado, mas para o país e a sociedade em geral. Embora envolvendo ainda baixos valores, devese levar em conta os dados levantados que apontam a música como um dos dois segmentos mais procurados pelos empresários para investimento e aquele cujos projetos conseguem altos índices de captação de recursos em Belo Horizonte. Um instrumento relevante seriam as campanhas de esclarecimentos ao setor empresarial - especialmente as empresas de pequeno e médio porte - sobre as Leis de Incentivo, além do estudo de formas de participação no incentivo fiscal para empresas tributadas com base no "lucro presumido". Essas propostas levam em conta os estudos de vários autores, entre eles HANSEN e BARRETO (2003, p.102), para quem, na Nova Economia - que inclui a Economia da Cultura -, "a vontade dos empresários é determinante para se definir as localizações das atividades econômicas".

Nesse processo, o grande potencial de geração de emprego, renda e impostos das atividades culturais, cuja estrutura de consumo intermediário as leva a um forte encadeamento com os demais setores da economia, torna-se argumento relevante. Os dados obtidos pela Fundação João Pinheiro (FJP, 2003a) mostram que as atividades culturais podem gerar um PIB maior do que a média gerada pelos demais setores da economia; que elas apresentam resultados superiores à média sobre a geração de emprego e a arrecadação (310 empregos gerados, em média, em festival/show/mostra, para cada $R \$ 1$ milhão consumido pelas famílias, enquanto na indústria automobilística o resultado é de 40 empregos, e em comunicações, 56). A capacidade de geração de ICMS das atividades culturais também apresenta, segundo a FJP (2003a), desempenho superior ao de segmentos produtivos consolidados (4\% do valor da produção dessas atividades, superior aos $2,6 \%$ de comunicações e a $0,8 \%$ de material de transporte) e constitui mais um argumento a ser utilizado.

Quanto às demais instituições que precisariam participar da criação do SPIL, Belo Horizonte dispõe de um elenco sólido e preparado, capaz de agregar condições extremamente favoráveis ao processo. São exemplos, a Fundação João Pinheiro (FJP) e o Serviço Brasileiro de Apoio às Micro e Pequenas Empresas (SEBRAE MG), duas instituições tradicionais, com experiência de se envolver em pesquisas e projetos ligados ao mercado da música da capital mineira e que têm demonstrado interesse em contribuir para a construção de políticas de cultura. O chamado Sistema $\mathrm{S}^{19}$, do qual o SEBRAE participa juntamente com as organizações dos setores produtivos (indústria, comércio, agricultura, transportes e cooperativas) - todas com sede ou representação em Belo Horizonte -, pode constituir relevante parceiro nesse processo.

A capital mineira também conta com importantes representações culturais estrangeiras, como o Instituto Cervantes (órgão oficial de difusão da cultura espanhola) e o Serviço de Cooperação e Ação Cultural da Embaixada da França - que poderiam constituir parceiros estratégicos do SPIL. Do ponto de vista das novas tecnologias - estreitamente ligadas ao desenvolvimento da música -, Belo Horizonte apresenta uma das melhores bases para um sistema de informação, do ponto de vista técnico, como lembra um dos entrevistados, 
o reitor da UFMG, professor Clélio Campolina Diniz"20: "nós somos, hoje, um grande centro criador de programas de software, inclusive com a criação da FUMSOFT" 21.

Entre as universidades, a UFMG, por sua história, infraestrutura e tradição no desenvolvimento de projetos culturais $^{22}$, qualifica-se como um importante ator desse processo. Seu atual Pró-Reitor de Extensão, professor João Antônio de Paula ${ }^{23}$, afirma que, por seu compromisso "com a cultura, com o saber, com o desenvolvimento", a UFMG se colocaria como uma instância adequada para contribuir para a criação das condições necessárias à criação do SPIL da música de Belo Horizonte no que diz respeito ao embate de ideias, a partir de seus diversos centros acadêmicos.

Para o professor, este seria um bom momento para tratar essa questão, uma vez que a UFMG, a partir da redefinição conceitual de um de seus maiores projetos culturais, 0 Festival de Inverno, estaria passando por um processo de discussão interna sobre temas que, por exemplo, levam em consideração o fato de que "a cultura, a arte etc. são instrumentos de discussão das identidades locais" e o de que "elas também têm esse potencial de alavancar recursos, captação, atração do turismo e tal". Ao defender uma postura da Universidade cada vez mais aberta e em sintonia com a sociedade, o reitor Clélio Campolina Diniz também vê "as atividades culturais como elementos centrais na formação humana, para o lazer, para uma sociedade mais democrática", defendendo um papel cada vez mais ativo da UFMG nesta área.

Ainda no âmbito das instituições superiores de ensino e pesquisa da capital, a Pontifícia Universidade Católica de Minas Gerais (PUC-MG) também poderá representar papel relevante neste SPIL. Desde 1999, oferece um curso de Pós-Graduação em Ciências Sociais, com área - única em Belo Horizonte - de concentração em Cidades: Cultura, Trabalho e Políticas Públicas, tendo como um de seus objetivos "qualificar, de forma mais densa, profissionais já integrados ao quadro da administração pública, de instituições privadas e de organizações não governamentais". O programa conta com linhas de pesquisa relacionadas ao objeto desse estudo, tais como: Cultura, identidades e modos de vida; e Políticas públicas, participação e poder local24.

Do ponto de vista das instituições governamentais, a pesquisa apontou clara fragilidade, tanto da Fundação Municipal de Cultura, quanto da Secretaria de Estado da Cultura principais órgãos gestores da área na capital -, no que diz respeito aos recursos humanos, técnicos e de infraestrutura que lhes permitam exercer adequadamente o seu papel de executor de políticas públicas voltadas para a legitimação e a universalização dos direitos culturais. Os estudos mostraram que, para uma atuação efetiva, voltada para os interesses reais da maioria da população, tais órgãos precisam sofrer profundas transformações do ponto de vista da gestão, buscando melhorar o fluxo de informações internas, a comunicação com a sociedade, a qualidade e agilidade no atendimento, além da eficiência na atuação.

Do ponto de vista político, será necessário um efetivo alinhamento desses órgãos com as demandas contemporâneas da área e da cidade. Para alcançar tal objetivo, um dos caminhos é a necessária interação entre os mesmos, visando o desenvolvimento de ações integradas e planejadas para criar políticas intersetoriais que busquem a difusão da produção musical da capital, tanto aquela voltada para a fruição quanto a produção com vistas à arte-educação. Nesse sentido, a ausência de informações consistentes, 
consolidadas e atualizadas sobre a cadeia produtiva da música da capital é um fator desfavorável. Como solução, a pesquisa apontou a necessidade de criação de sistemas de informação e indicadores culturais municipal e estadual. O Sistema Nacional de Informações e Indicadores Culturais (SNIIC) - recém-criado pelo Ministério da Cultura pode servir de modelo e importante ponto de partida desse processo. A larga experiência da Fundação João Pinheiro no desenvolvimento de pesquisas na área cultural, que pode levá-la a contribuir nesse processo, também é fator favorável.

Para que essas políticas de desenvolvimento do setor estejam conectadas com a realidade do segmento musical e em sintonia com uma política de desenvolvimento econômico e social local, será preciso uma ação planejadora e reguladora do Estado, neste caso, da Prefeitura. Para ser eficaz, essa ação deverá partir de duas perspectivas principais. A primeira diz respeito ao reconhecimento e ao fortalecimento do que existe na cidade, do que o segmento musical já está produzindo, do ponto de vista do interesse público. A segunda passa pela construção de elos entre o segmento musical e os demais setores da sociedade, por meio de uma rede de relações cuja dinâmica signifique uma transformação qualitativa na experiência desses atores, na perspectiva de uma transformação maior do processo social, dentro da lógica defendida por CASTELLS (2003, p.572) de que "o poder dos fluxos é mais importante do que os fluxos do poder".

Tais políticas deverão contemplar algumas diretrizes básicas, tais como a inter-relação entre todos os elos da cadeia produtiva da música; o aprendizado e a difusão - entendida como parte do processo inovativo - do conhecimento codificado e tácito; a diminuição da informalidade do setor; o estímulo ao exercício da profissão de músico na capital; a continuidade do trabalho artístico; a necessidade de formação de plateias; e a importância de se ampliar as fontes de financiamento (públicas e privadas), conciliando-se os recursos injetados na cultura por meio do incentivo fiscal com os investimentos com recursos do Tesouro. Aqui, é preciso considerar que - como defendem HANSEN e BARRETO (2003) - nesse novo modelo que envolve a Economia da Cultura, inovação e adaptação às mudanças tecnológicas são fundamentais e a capacidade criativa tem mais peso do que 0 porte do capital a ser investido.

\subsubsection{Cultura como investimento}

Entre as ações consideradas prioritárias na elaboração de um plano para a organização do SPIL proposto, duas foram destacadas na presente pesquisa: a) o fomento de público; b) a criação ou fomento de condições de incentivos, apoios, promoções, parcerias e financiamentos que resultem na divulgação e no fomento da produção musical como um todo, para que o sucesso não se restrinja a projetos pontuais, dependentes de esforços particulares ou de privilégios de ocasião. Trata-se, aqui, de enfrentar uma dificuldade comum a toda a área, que sempre precisa defender que a cultura seja reconhecida como investimento, e não despesa. Investimento nos valores, na criatividade, na imagem da cidade (no estado, no país e no exterior) e na geração de emprego, renda e inclusão socioeconômica, como argumenta REIS (2002).

Como destacou o músico Geraldo Vianna ${ }^{25}$, para quem a criação do SPIL deve levar em conta "o aspecto empresarial da arte", porque "a música, a arte, ela nunca acaba, mas ela precisa de suporte para virar produto". Isto significa criar ações voltadas para a economia da música em todos os seus aspectos - de planejamento, organização, financiamento, monitoramento e avaliação -, com o objetivo de se construir políticas estruturantes de 
Estado, que ultrapassem as políticas conjunturais de governo - sujeitas aos humores e desejos particulares dos governantes do momento.

Constatou-se a urgência de que o debate sobre o desenvolvimento de Belo Horizonte incorpore a compreensão da necessidade de interação entre processos culturais, econômicos e sociais, na perspectiva da contribuição da cultura ao desenvolvimento local, além da geração de recursos econômicos. Como defende SILVA (2007, p.19), "a cultura perpassa todas as dimensões da vida em sociedade e se relaciona com processos de sociabilidade e sua reprodução". Embora exista alguma sensibilidade por parte do Governo do Estado, como demonstra a recente criação da Orquestra Filarmônica de Minas Gerais e o apoio ao projeto Música Minas ${ }^{26}$, por exemplo, o não entendimento da dimensão econômica da cultura e do papel estimulador de desenvolvimento social que ela pode desempenhar transparece na falta de uma política estadual clara, com objetivos definidos, metas, programas e projetos estruturantes para a área.

A dificuldade para se viabilizar o programa Música Minas é um exemplo dessa situação, que é a mesma enfrentada por outros programas estaduais importantes para a cultura, como o Filme em Minas - de estímulo ao audiovisual - e o Cena Minas, realizado desde 2007, com o objetivo de "incentivar e fortalecer as produções cênicas no Estado, nas áreas do teatro, da dança e do circo". ${ }^{27}$ Nenhum deles está institucionalizado, não dispondo, portanto, de dotação orçamentária própria. A implantação do Conselho Estadual de Cultura - demanda urgente da área cultural - poderá contribuir para avançar essa discussão.

No âmbito municipal a situação mostra-se ainda mais precária. Do ponto de vista político, o fato que chama mais atenção é a perda de status da Secretaria de Cultura, transformada em fundação, o que retira da área o poder de participar, em pé de igualdade com as demais secretarias, da construção e discussão das políticas públicas da cidade. Por outro lado, a necessidade de uma fundação capaz de responder ao dinamismo da gestão cultural também está demonstrada. A falta de recursos, entretanto, tem sido apontada como impeditivo para que os dois órgãos coexistam. A situação, portanto, parece sinalizar para a necessidade de uma ampla discussão a partir das instâncias da própria Prefeitura, no sentido de buscar solução mais adequada para o problema. O que parece não ser concebível é que a terceira mais importante capital do país, detentora de grande e expressivo volume de produção cultural em absolutamente todas as áreas, possa se conformar em continuar a ter a cultura fazendo parte da administração indireta do município.

Outro problema do ponto de vista institucional a ser enfrentado diz respeito à adequação da Prefeitura para participar do recém-criado Plano Nacional de Cultura (PNC), grande conquista recente da cultura brasileira. Segundo este Plano, o Sistema Nacional de Cultura (SNC) - cujo projeto de lei encontra-se em fase final de tramitação no Congresso Nacional - "será o principal articulador federativo do PNC, estabelecendo mecanismos de gestão compartilhada entre os entes federados e a sociedade civil" ${ }^{28}$. Para aderir ao PNC, o município deve assumir o compromisso de criar, até 31 de dezembro de $2011^{29}$, o seu Sistema Municipal de Cultura, composto por, pelo menos, cinco instâncias obrigatórias. 
Belo Horizonte ainda precisa criar duas dessas instâncias: o Conselho Municipal de Política Cultural e o Plano Municipal de Cultura. Três já existem: o órgão gestor municipal de cultura, no caso, a FMC; o sistema municipal de financiamento à cultura (a Lei Municipal de Incentivo à Cultura); e a Conferência Municipal de Cultura, embora a sua segunda edição, realizada em outubro de 2009, não tenha tido nenhuma sequência por parte do encaminhamento e da operacionalização de suas resoluções pela Prefeitura, até março de 2011.

A importância da cidade se preparar para integrar o Sistema Nacional de Cultura não se restringe apenas à garantia de verbas do governo federal. Trata-se de participar da maior e mais efetiva iniciativa governamental em defesa da cultura brasileira, que, pela primeira vez na história do país, vem trabalhando com base em amplo e profundo planejamento, criando sistemas de informações e indicadores e procurando institucionalizar planos e políticas para a área, com a participação da sociedade.

Do ponto de vista das ações, constatou-se que as políticas desenvolvidas pela Fundação não refletem a dimensão atual da diversidade cultural da cidade. Por exemplo, não há registro de projeto municipal voltado para o fomento e a difusão da música, apesar de toda a efervescência do segmento. Ao contrário, a pesquisa mostrou que o segmento musical tem feito grande esforço, sem sucesso, para chamar a atenção do gestor público municipal e, em alguns casos, até mesmo para se desvencilhar dos obstáculos criados por ele.

Exemplos mais contundentes são o Quarteirão do Soul - encontro nas tardes de sábado na região central da capital, criado em 2004 pelos apreciadores da soul music - e o Duelo de MCs (Mestres de Cerimônias), realizado desde 2008 debaixo do viaduto Santa Tereza, reunindo manifestações artísticas do Hip Hop. Como legítimos representantes de gêneros musicais abraçados por grandes parcelas da população da cidade e que dependem do espaço público para suas apresentações, espera-se que sejam reconhecidos pela Prefeitura e que a mesma crie, democraticamente, políticas claras de ocupação dos espaços públicos.

Nessa perspectiva, a pesquisa mostrou a necessidade de uma discussão pública na cidade sobre o conceito de espaço cultural. Será que espaço cultural é só aquele espaço físico, o equipamento público, o teatro, a galeria etc.? Ou "existem esquinas?", como lembrou a antropóloga Marcela Bertelli30: "olha como uma esquina foi tão importante pra essa cidade, reconhecida como um espaço de cultura" ${ }^{31}$. Os dados apontam a necessidade de se reconhecer essas realidades vivas, essas manifestações culturais espontâneas, nos ambientes onde elas surgem - sejam eles públicos ou privados, menos ou mais qualificados -, percebendo-os como espaços simbólicos da cultura.

Os dados colhidos mostram a existência de um verdadeiro abismo entre o que acontece no segmento musical da cidade e as ações da Fundação Municipal de Cultura. A gestão da Fundação mostra-se em total desconexão quanto ao "desenvolvimento cultural" que propõe ${ }^{32}$ e às suas ações relacionadas, principalmente, aos movimentos culturais locais, ao entendimento de cultura como um direito social e aos usos coletivos dos espaços públicos. O quadro encontrado aponta para a necessidade urgente de que a FMC se abra para o que acontece na cidade, para o imprevisível, tomando como ponto de partida a realidade local - não apenas a estrutural, mas a necessidade criativa, inventiva - e o 
interesse público, por meio do estabelecimento de canais de participação e de diálogo com a sociedade, buscando corresponder ao que se espera de seu papel.

Ainda no que diz respeito à Fundação Municipal de Cultura, outra ausência sentida é a de projetos de formação de plateias. A pesquisa apontou a existência, em Belo Horizonte, de público interessado e capaz de fruir a música. Entretanto, observou-se a necessidade de investimentos permanentes na formação de plateias, voltados tanto para a sensibilização de crianças e jovens, nas escolas, quanto para os adultos - condição essencial para a construção do SPIL proposto. Uma forma de enfrentar este problema seria o desenvolvimento de campanhas que visem sensibilizar o público para o ato de fruição da música e para a importância da produção musical mineira. Outra seria a implantação de projetos musicais didáticos de longa duração, que contribuam para maior informação e formação do público, no sentido de estimulá-lo a buscar qualidade e a ficar mais atento às inovações.

Ainda nessa perspectiva, outra medida importante seria a criação de uma comissão no âmbito da FMC, formada por professores, pedagogos e músicos, com o objetivo de acompanhar a implantação da disciplina de educação musical no currículo das escolas municipais, para garantir que se alcance o espírito da lei de desenvolver nos alunos sensibilidade, criatividade e capacidades pessoais. Como uma estratégia para se alcançar tal objetivo, propõe-se o desenvolvimento do canto coral, por meio da criação de corais nas escolas públicas municipais. A referida comissão poderia se encarregar da elaboração de projeto de lei sobre o assunto. Dois argumentos básicos justificam essa proposta. Primeiro, a combinação facilidade e baixo custo na viabilização de um coral, o qual exige basicamente dois profissionais - o regente e o pianista - e um piano, não envolvendo a aquisição e manutenção de grande quantidade de instrumentos musicais. Em segundo lugar, porque o coral seria um caminho mais simples para se trabalhar as crianças, visando o desenvolvimento de um sentimento coletivo e de disciplina, além da sensibilidade.

Para atender ao público das vilas e favelas ${ }^{33}$ - bastante significativo e cada vez mais presente na produção musical da capital -, a pesquisa apontou a necessidade de uma oferta permanente e variada de projetos culturais a essas comunidades, que permitam às pessoas a assimilação das novas linguagens e gêneros e a criação do hábito de consumo cultural. E que essa oferta leve em conta a crescente e dinâmica produção cultural dessas comunidades, que demanda políticas públicas de apoio e incentivo.

Em relação à capacitação profissional dos principais atores envolvidos nesse sistema músicos, produtores e técnicos -, Belo Horizonte mostra-se bastante preparada no que diz respeito à formação artística, com oferta de cursos variados e de alta qualidade, o que se configura como fator altamente favorável ao SPIL da música. Também na área da capacitação de produtores foram registradas iniciativas importantes, como alguns cursos de nível superior e treinamentos oferecidos pelo SEBRAE MG e pela ONG Favela é isso Aí, entre outras instituições. As falhas nessa área foram detectadas em relação à capacitação técnica.

A baixa oferta de cursos de formação de técnicos e demais profissionais vinculados à infraestrutura (iluminadores, sonoplastas, cenógrafos, técnicos de mixagem e masterização etc.) tem gerado deficiência na oferta de mão de obra especializada, 
principalmente para a realização de shows e grandes espetáculos. Um caminho para enfrentar tal problema seria o mapeamento das demandas reais nessa área e a realização de parcerias com as empresas fornecedoras dos equipamentos de som e luz, por exemplo, ou com o Sistema S, no sentido de suprir essas demandas. Também a UFMG poderia se tornar outro grande parceiro, a partir do oferecimento de cursos de extensão nessa área. A construção dessas parcerias poderia fazer parte das estratégias de articulação do Fórum.

\subsubsection{Cultura: alicerce da economia}

Quanto aos recursos financeiros, a ampliação das fontes de financiamento, públicas e privadas, e o aumento da dotação orçamentária para a área - cujo índice almejado é baseado na proposta de $1 \%$ do orçamento municipal prevista em projeto de lei em tramitação no Congresso Nacional -, são iniciativas essenciais para acabar com a atual dependência do segmento dos recursos provenientes dos mecanismos de incentivo fiscal. Propõe-se, ainda, a criação de um mecanismo misto de financiamento, envolvendo a iniciativa privada e o setor público, que, a partir da participação financeira efetiva e não reembolsável do realizador, Ihe assegure a possibilidade de comercialização do produto patrocinado. Tais medidas, associadas à reformulação das diretrizes das leis de incentivos fiscais, municipal e estadual - no que diz respeito à lógica da concorrência não artística e do atendimento pontual desses mecanismos -, contribuiriam para a valorização do trabalho artístico e o respeito ao profissional das artes, em geral, e da música, em particular.

Esta inversão de proporção entre as fontes de financiamento - garantindo o fluxo permanente de recursos e a democratização de acesso aos mesmos - é condição essencial para a construção de políticas estaduais e municipais para o segmento e, consequentemente, para a construção do SPIL proposto. Nesse sentido, a criação do Sistema Municipal de Informações e Indicadores Culturais proposto torna-se fundamental para permitir pensar lógicas de financiamento coerentes com a realidade local. Pensandose em planejamentos de médio e longo prazos, as atuais características urbanas da capital - seus limites territoriais encontram-se conurbados com outros seis municípios ${ }^{34}$ apontam a necessidade de que esse sistema assuma caráter intermunicipal, o que irá demandar interações e articulações com os municípios da região.

Faz-se necessária, ainda, uma observação quanto à utilização dos recursos do orçamento destinados à cultura. Além do montante disponível, é preciso, também, estar atento a como e onde ele é aplicado, ou, em alguns casos, até mesmo garantir que o que foi destinado para a área esteja sendo realmente aplicado nela. No tocante à Fundação Municipal de Cultura de Belo Horizonte (FMC), dados da prestação de contas da execução orçamentária de $2010^{35}$ mostram que o órgão utilizou apenas $61 \%$ da verba prevista para aquele ano, constituindo-se em um dos orçamentos menos executados entre todos os órgãos da Prefeitura. Há que se levar em conta, ainda, que a maior parte desses recursos foi gasta com pagamento de pessoal, encargos sociais e serviços administrativos do próprio órgão. As causas disto podem ser diversas, do despreparo do órgão para operar esse dinheiro, por exemplo, à falta de interesse da gestão municipal em investir em cultura. O que fica claro, entretanto, é que a área da cultura não está recebendo o tratamento que seus atores esperam e demandam do poder público. 
Sobre a ausência de políticas públicas voltadas para a área, tanto por parte da Prefeitura quanto do Governo Estadual, o professor João Antônio de Paula afirma que estaria faltando uma compreensão de que a economia da capital mineira, por não poder ser pensada do ponto de vista da produção industrial, até por falta de espaço, poderia ter na cultura um de seus principais alicerces, já que "as atividades culturais agregam muito valor, têm impacto ambiental nenhum, pelo contrário, são até preservacionistas, totalmente sustentáveis e têm um impacto, uma capacidade de atração do turismo muito forte". A música poderia se transformar em "um elemento de atração turística", como concorda Diniz, tendo em vista a deficiência da capital no que diz respeito a grandes atrativos nesse setor.

Tal entendimento vem ao encontro da visão de vários autores, entre eles REIS (2008), de que a economia da cultura integra o segmento de serviços e lazer, cuja projeção de crescimento tem sido superior à de qualquer outro, estimando-se que esteja crescendo $10 \%$ ao ano. Tal potencial de crescimento é considerado bastante elástico, uma vez que o setor depende pouco de recursos esgotáveis, sendo o seu insumo básico a criação artística ou intelectual e a inovação.

Outro conjunto de problemas encontrado está relacionado à necessidade de criação de mercados para consumo do produto musical da capital, não apenas local, mas além dos limites do estado e do próprio país. A esse respeito, a pesquisa mostrou que Belo Horizonte apresenta vários fatores desfavoráveis. Levando-se em conta o dado encontrado de que as apresentações ao vivo são a principal unidade produtiva do mercado da música da capital, a ausência de espaços apropriados e de condições adequadas para a prática dessa atividade constitui uma dificuldade significativa. Para enfrentá-la, uma medida que assume caráter de urgência é a que diz respeito à necessária articulação entre os três poderes (municipal, estadual e federal), visando potencializar o aproveitamento dos espaços culturais públicos existentes e a serem inaugurados em Belo Horizonte - a exemplo do Centro Cultural Banco do Brasil e do Espaço Cultural Funarte -, para que contemplem a produção musical local.

Em relação aos bares e restaurantes, propõe-se, a partir do Fórum da Música, um trabalho de aproximação com os donos das principais casas ou daquelas que já apresentem alguma condição de realizar shows, com o objetivo de atraí-los para o debate sobre a criação do SPIL, sensibilizando-os para o retorno econômico e financeiro que poderão alcançar, além da contribuição que poderão dar ao desenvolvimento cultural e social da cidade. Essa aproximação também poderá facilitar o desenvolvimento de campanhas conjuntas que busquem trabalhar o público desses espaços para a arte da fruição da música, outro problema a ser enfrentado. Em contrapartida, sugere-se a criação de linhas de crédito especiais, além de isenções fiscais, que favoreçam os estabelecimentos privados que empregam músicos locais para apresentações ao vivo, auxiliando-os na aquisição de instrumentos e equipamentos musicais, de sonorização e iluminação, e de aparelhagem para se adequarem às exigências da Lei do Silêncio.

Diante da expressiva e relevante produção musical belo-horizontina, propõe-se que a Prefeitura crie um espaço público municipal voltado especificamente para os espetáculos musicais, já que todos os espaços disponíveis hoje na cidade são teatros adaptados para shows. Uma proposta seria preparar o Teatro Francisco Nunes - único de propriedade da $\mathrm{PBH}$ e que se encontra fechado há dois anos - para receber espetáculos de música, 
dotando-o de qualidade acústica e equipamentos apropriados. Por sua origem - foi criado como casa da ópera -, localização privilegiada (no Parque Municipal, centro da cidade), estrutura de porte médio (cerca de 600 lugares) e pelo próprio artista que lhe dá nome ${ }^{36}$, Chico Nunes, como é conhecido, poderia ser caracterizado como a Casa da Música de Belo Horizonte, constituindo um equipamento público cultural diferenciado. Esta Casa da Música - além de atender à demanda do segmento musical belo-horizontino - pode se transformar em referência para o turismo cultural da capital.

Ao lado disso, propõe-se, ainda, que a Prefeitura, por meio da FMC, também invista na criação da Orquestra Sinfônica Jovem de Belo Horizonte. Além de a pesquisa ter apontado a existência de público significativo para a música erudita na capital mineira, que comparece em peso aos espetáculos do gênero produzidos na cidade, este tipo de projeto se justifica pelo importante papel que desempenha na formação dos jovens, além de poder contribuir com o processo de formação de plateias. Compreende-se, entretanto, que, para que essas propostas tenham receptividade, é preciso que a Prefeitura adote postura mais sensível em relação ao papel da cultura, especialmente à importância da música para a economia e o desenvolvimento social de Belo Horizonte, reconhecendo e valorizando a efervescente produção do segmento.

É preciso, também, um trabalho articulado entre a Fundação Municipal de Cultura e a Secretaria Estadual de Cultura, visando criar ações coordenadas para divulgar os artistas e a produção musical locais, não apenas para a população da capital, mas a do interior e a do resto do país. Nessa direção, assume relevância a proposta de criação pelo governo estadual de escritórios culturais nas cidades polo do estado, que possam cumprir esse papel. Concomitantemente, é preciso que o poder público crie mecanismos próprios de divulgação, a partir de planejamento e projetos específicos que busquem alcançar o público por meio de instrumentos de comunicação tanto físicos quanto virtuais: impressos (jornais, folders, catálogos etc.), programas de rádio, vídeos, sites, blogs etc. Este material, ao lado de recursos humanos capacitados, bem informados e articulados, será fundamental para o funcionamento desses escritórios.

Também é preciso investir em divulgação na mídia tradicional e nas rádios comunitárias, particularmente as do interior, aproveitando o seu potencial local. Do ponto de vista da divulgação, o Fórum da Música pode desempenhar papel estratégico essencial, criando, articulando e apoiando projetos que contribuam para a difusão da produção de Belo Horizonte. As universidades locais devem ser estimuladas a oferecerem cursos, workshops etc. que estimulem e contribuam para a formação de críticos musicais.

Em relação ao governo estadual, faz-se necessária a construção de uma política de divulgação dessa produção nas mídias estatais (Rede Minas de Televisão e Rádio Inconfidência). Para alcançar tal objetivo, torna-se fundamental que os dirigentes dessas instituições, particularmente os diretores artísticos, sejam escolhidos a partir de critérios que levem em conta a formação e a qualificação para o desempenho no cargo. Propõese, ainda, verificar-se a possibilidade de se estabelecer uma parceria entre a Rádio Inconfidência e a Empresa Brasil de Comunicação (EBC) para o intercâmbio de programação com a Rádio MEC, empresa estatal educativo-cultural, a exemplo do que já ocorre entre a TV Minas e a TV Brasil (também pertencente à EBC). Esta veicula programas da TV mineira e cede programas da sua grade para veiculação na programação da emissora local. A rica produção atual e o grande acervo da Rádio MEC ${ }^{37}$, 
voltados para a música de qualidade, popular e erudita, serão de grande contribuição para qualificar a programação da Rádio Inconfidência.

\subsubsection{Economia da música}

Instrumentos importantes para a difusão e a comercialização da produção musical são os festivais - que além de lançarem novos artistas, possuem uma cadeia produtiva completa -, os concursos e os prêmios. Assim, propõe-se a criação - pela FMC, em parceria com o Fórum da Música - do Festival de Música de Belo Horizonte, na linha dos recentes festivais independentes, sem caráter competitivo, mas sim de mostra da produção local, com periodicidade bienal, e do Prêmio da Música de Belo Horizonte, também bienal, cujos anos de realização seriam intercalados. No âmbito estadual, a volta do circuito de festivais no interior seria oportunidade eficiente de intercâmbio da produção das diferentes regiões, de fomento de plateias e de geração de trabalho e renda para o segmento.

Tais iniciativas poderão constituir grandes vitrines para a música da capital, colaborando para aumentar sua visibilidade nacional e internacional e constituindo, ainda, atrativos turísticos específicos. Trabalhados intersetorialmente e de forma integrada pelos governos municipal e estadual, estes atrativos poderão contribuir efetivamente para a geração de trabalho e renda na capital muito além da cadeia produtiva da música, alcançando setores como a rede de hotéis, a cadeia de bares e restaurantes, o comércio em geral, entre outros. Essas propostas são exemplos de ações que podem associar o desenvolvimento do segmento musical às políticas de fomento do turismo local e estadual, agregando à cadeia produtiva da música outro papel importante no processo de desenvolvimento social - 0 de indutora do turismo da capital. Dialeticamente, 0 desenvolvimento do turismo pode se transformar em condição importante para o SPIL da música de Belo Horizonte, aumentando o mercado consumidor de seus produtos e contribuindo para a difusão da sua produção fora dos limites da capital.

A capital mineira - hoje com boa hotelaria e aeroporto internacional - tornou-se um portão de chegada e um centro distribuidor de turistas para os três principais circuitos turísticos do estado: das cidades históricas, das estâncias hidrominerais e do ecoturismo. A oferta planejada de atrações musicais pode contribuir para que a cidade - com pouquíssimas atrações turísticas - deixe de ser apenas uma rota de passagem para esses turistas.

Faz-se importante ressaltar que Belo Horizonte possui uma população de 2.375 .444 habitantes $^{38}$, sendo a sexta cidade mais populosa do país. Além disso, a região metropolitana na qual se insere eleva esse contingente populacional para cerca de cinco milhões de habitantes ${ }^{39}$, o que amplia significativamente o raio de ação do seu mercado, inclusive o da música. Se, desses cinco milhões, considerarmos, numa leitura conservadora, que 50 ou 100 mil têm interesse em apreciar música, já se pode inferir a existência do que os economistas chamam de densidade de mercado, isto é, que há na própria região número suficiente de consumidores potenciais para sustentar o mercado da música de Belo Horizonte, numa economia de escala.

Outro aspecto relevante a ser considerado é a direção da economia da capital para o setor terciário - comércio, prestação de serviços e setores de tecnologia de ponta ${ }^{40}$, principalmente, pela saturação do espaço físico e pelo adensamento do tecido urbano, o que tem levado ao fortalecimento do turismo de negócios ${ }^{41}$ e de eventos (congressos, convenções, feiras, exposições, eventos técnico-científicos etc.). Dessa forma, ganham 
destaque as atividades culturais, em geral, e a música, em particular - intimamente ligadas às estratégias atuais das empresas e instituições de divulgação de produtos e fidelização dos clientes por meio de eventos. Desse ponto de vista, a música tem grandes contribuições a oferecer, com o incremento na realização, por exemplo, de feiras de negócios e seminários sobre o próprio segmento, aproveitando toda a expertise e infraestrutura locais.

A realização de eventos tem sido um dos carros-chefes do marketing do setor terciário. Além de se tornar cada vez mais comum a apresentação de músicos nas solenidades de abertura e encerramento de congressos e convenções, tem aumentado o número de empresas que utilizam os shows como peças importantes do seu planejamento de marketing, representando crescente nicho de mercado para os músicos. O fortalecimento do turismo de eventos, além de incrementar os níveis de ocupação da rede hoteleira e do consumo dos serviços de bares, restaurantes e transportes, como já acontece hoje, pode também contribuir para o fomento da produção musical de Belo Horizonte.

Esta questão promete ganhar nova dimensão na capital mineira - uma das sedes da Copa do Mundo de 2014 - com o lançamento de empreendimentos para atender à demanda de hóspedes durante o Mundial. Segundo pesquisa do Fórum de Operadores Hoteleiros do Brasil (FOHB) ${ }^{42}$, depois da Copa do Mundo, Belo Horizonte - cujo número de hotéis saltará de 103 para pelo menos 133, podendo chegar a 144 unidades precisará atrair cerca de 20 mil turistas por semana, gerando uma média de 40 mil diárias, para não ter prejuízos com quartos ociosos. Isto significa que a cidade precisará incrementar o turismo de negócios e eventos, o que aumenta a perspectiva para a produção musical local e a relevância da criação do SPIL da música.

Um aspecto importante, associado ao Mundial de futebol e a seus desdobramentos, é a possibilidade de divulgação da cultura mineira, em especial da música, que será criada com a vinda de milhares de turistas estrangeiros a Belo Horizonte. Trata-se de uma oportunidade ímpar, que deverá ser aproveitada pelo segmento musical, o qual, para tanto, deve se preparar com antecedência, estimulando e cobrando do poder público investimentos em projetos nessa direção. Uma proposta é a criação de programação bilíngue para TV, voltada para a divulgação da produção musical da capital, para ser veiculada nos circuitos internos de TV do Aeroporto de Confins e dos demais aeroportos internacionais do país. Ainda do ponto de vista do turismo, a criação de projetos de música associados aos eventos do circuito Estrada Real seria uma oportunidade de difundir a produção musical mineira e, ao mesmo tempo, contribuir para a consolidação desta importante iniciativa turística.

Tais ações representam apenas uma das facetas que a economia da música de Belo Horizonte pode adquirir. Como já analisado, é preciso ter sempre em perspectiva que o impacto econômico da cultura em sua cadeia de fornecedores diretos e indiretos é maior do que o gerado pelas demais atividades de serviços (comércio, transportes, comunicações, etc.) - como apontam estudos da FJP (2003a) -, o que significa que os gastos em cultura geram proporcionalmente mais emprego e renda que os realizados nas outras atividades. Estes efeitos somente não são sentidos de forma significativa no conjunto da economia devido ao reduzido tamanho econômico da cultura. A solução natural, portanto, é o investimento cada vez maior na área. 


\section{4 - Considerações finais}

A pesquisa mostrou que a construção de um sistema produtivo e inovativo local exige articulação institucional envolvendo a sociedade civil e o governo e, também, intencionalidade. A atual conjuntura cultural belo-horizontina indica que essa intenção deve partir da própria sociedade civil, isto é, dos músicos, por meio de suas entidades representativas. A partir daí, deve-se procurar a interação com os governos do estado e do município, assim como com os demais atores importantes para o sistema, como os empresários e as instituições de ensino e pesquisa. Para tanto, faz-se necessária a existência de um mecanismo que possibilite a aproximação das partes, garantindo-lhes reciprocidade no todo, de modo a dar sustentação a um processo social, econômico e político capaz de catalisar essas energias e potencialidades, em prol do segmento da música e do desenvolvimento local.

Nessa perspectiva, propõe-se, como primeiro passo institucional para a criação deste SPIL, a constituição da Câmara Setorial da Música de Belo Horizonte, como uma instância mediadora permanente, um espaço que contribua para qualificar a discussão de estratégias e de políticas para o segmento mediante o estímulo à aproximação territorial dos diferentes agentes locais. Esta instância deve ser constituída por representantes dos músicos, da Prefeitura, do Governo do Estado, do Governo Federal, dos empresários e das instituições de ensino e pesquisa da capital. O projeto detalhando esta proposta, bem como a íntegra da dissertação que deu origem a este artigo está disponível em: http://www.mestradoemgsedl.com.br/wpcontent/uploads/2010/06/Disserta\%C3\%A7\%C3\%A3o-Jane.pdf.

\section{Referências}

ALVES-MAZOTTI, Alda J.; GEWANDSZNAJDER, Fernando. O Método nas Ciências naturais e Sociais. São Paulo: Pioneira, 1998, p.147-189.

ANDRÉS, Artur; BORÉM, Fausto. O grupo UAKTI: três décadas de música instrumental e de novos instrumentos musicais acústicos. Per Musi, Belo Horizonte, n.23, 2011, p.170-184.

CARSALADE, Flavio de L. Culture as a methodological key. City \& Time. Centro de Estudos Avançados da Conservação Integrada. UFPe, n. 2, v. 1. Olinda, PE: 2005. Disponível em: www.ct.ceci-br.org. Acesso em: 11 Jan. 2010.

CASTELLS, Manuel. A Sociedade em Rede. V. 1. São Paulo: Paz e Terra, 2003. 698 p.

CASTRO, Célio de. BH 100 anos - uma lição de história. Prefeitura de Belo Horizonte. 1997. Disponível em: http://portalpbh.pbh.gov.br/pbh/ecp/comunidade.do?evento=portlet\&pldPIc=ecpTaxonomiaMenuPortal\&app= historia\&tax $=11794 \&$ lang $=\mathrm{pt}$ BR\&pg $=5780 \& \operatorname{taxp}=0 \&$.

FUNDAÇÃO JOÃO PINHEIRO. Centro de Estudos Históricos e Culturais. Prestando contas aos mineiros avaliação da Lei Estadual de Incentivo à Cultura. Belo Horizonte: 2003a. 87p. Disponível em:

http://www.fjp.gov.br/index.php/servicos/82-servicos-cepp/75-prestando-contas-aos-mineiros-avaliacao-dalei-estadual-de-incentivo-a-cultura. Acesso em: 10 Out. 2010.

HANSEN, Dean Lee; BARRETO JR, Édison R. Cenários de desenvolvimento local: estudos exploratórios, v. 1. Aracaju: SEPLAN, 2003, p.97-126.

REDE DE PESQUISA EM SISTEMAS PRODUTIVOS E INOVATIVOS LOCAIS. Mobilizando

Conhecimentos para Desenvolver Arranjos e Sistemas Produtivos e Inovativos Locais de Micro e Pequenas Empresas no Brasil. Glossário de Arranjos e Sistemas Produtivos e Inovativos Locais - GASPIL. LASTRES, Helena M. M.; CASSIOLATO José Eduardo (Coords.). $8^{\circ}$ rev., dez. 2005. Disponível em:

http://redesist.ie.ufri.br/glossario.php. Acesso em: 09 Jul. 2010.

MARTINS, Bruno V. Som imaginário - A reinvenção da cidade nas canções do Clube da Esquina. Belo Horizonte: UFMG, 2009. 233 p.

MINAS GERAIS. Secretaria de Estado da Cultura de Minas Gerais. Música Minas. 2009. Disponível em: http://www.cultura.mg.gov.br/?task=interna\&sec=1\&cat=39\&con=1511 Acesso em: 10 Jan. 2011.

PORTA, Paula. 2008. Economia da cultura: um setor estratégico para o país. Prodec/MinC. Disponível em: http://www.cultura.gov.br/site/2008/04/01/economia-da-cultura-um-setor-estrategico-para-o-pais/. 
REIS, Ana Carla F. Marketing cultural e financiamento da cultura. São Paulo: Thomson Pioneira, 2002. 313 p.

REIS, Ana Carla F. (Org.). Economia Criativa como estratégia de desenvolvimento: uma visão dos países em desenvolvimento. São Paulo: Itaú Cultural, 2008. 268 p. Disponível em:

http://www.garimpodesolucoes.com.br/downloads/ebook br.pdf. Acesso em: 18 Out. 2010.

SILVA, Frederico A. Barbosa da. Economia e Política Cultural: acesso, emprego e financiamento. Coleção Cadernos de Políticas Culturais. v. 3. Brasília, Ministério da Cultura, 2007. Disponível em: http://www.ipea.gov.br/082/08201004.jsp?ttCD CHAVE=2804. Acesso em: 14 Out. 2010. WERKEMA, Mauro G. História, arte e sonho na formação de Minas. Belo Horizonte: Duo Editorial, 2010. $504 \mathrm{p}$.

1 Extraído da dissertação apresentada ao Mestrado em Gestão Social, Educação e Desenvolvimento Local do Centro Universitário UNA, aprovada em 18 de Abril de 2011. Área de concentração: Inovações Sociais, Educação e Desenvolvimento Local. Linha de pesquisa: Processos Sociais e Políticos: Articulações Institucionais e Desenvolvimento Local. Orientadora: Profa. Dra. Lucília Regina de Souza Machado

2 Bahia, Espírito Santo, Rio de Janeiro, São Paulo, Mato Grosso do Sul e Goiás.

3. A Fundação João Pinheiro (FJP) realizou, em 1996, o 1ำ Guia Cultural de Belo Horizonte e, em 2003, publicou os estudos Prestando contas aos mineiros - avaliação da Lei Estadual de Incentivo à Cultura e Incentivo fiscal à cultura: limites e potencialidades. Em 2010, o jornalista Mauro Werkema lançou o livro História, arte e sonho na formação de Minas.

${ }^{4}$ Fonte The Globe and Mail de 23 Mar. 2006. Disponível em: http://www.theglobeandmail.com/search/?q=Grupo+Corpo+Brazil. Acesso em: 04 Abr. 2010.

${ }^{5}$ Com 33 anos de carreira, "tem trabalhado para manter sua herança africana em seus trabalhos artísticos tais como a música, dança, TV, teatro e cinema". Tornou-se capitão da Guarda de Moçambique - grupo que celebra o Congado. Idealizador e coordenador do Grupo Tambor Mineiro, cujo objetivo é resgatar e valorizar a cultura de Minas. Fonte: site Tizumba. Disponível em: http://www.tizumba.com/home.php?pag=1. Acesso: 05 Mar. 2011.

${ }^{6}$ Um dos três corpos artísticos mantidos pela Fundação Clóvis Salgado, a OSMG foi criada em 1976. Fonte: site da FCS. Disponível em: http://www.fcs.mg.gov.br/grupos-profissionais/82,,orquestra-sinfonica.aspx. Acesso em: 10 Mar. 2011

${ }^{7}$ Criada em 1986, a orquestra, mantida pelo Serviço Social da Indústria trabalha com formação de público e se apresenta com vários solistas e convidados de expressão nacional. Fonte: site da FIEMG. Disponível em: http://www.fiemg.org.br/Default.aspx?tabid=4005. Acesso em: 10 Mar. 2011

${ }^{8}$ Vinculada à Secretaria de Estado da Cultura, tem como principais finalidades "apoiar a criação cultural, fomentar, produzir e difundir as artes e a cultura no Estado", "administrar o Palácio das Artes, a Serraria Souza Pinto e demais espaços que the forem designados". Fonte: http://www.fcs.mg.gov.br/home/default.aspx. Acesso em: 10 Mar. 2011

${ }^{9}$ Fonte: Jornal Estado de Minas de 03/06/2009. Disponível em: http://www.em.com.br. Acesso em: 10 Mar. 2010.

${ }^{10}$ Em 2008, o SEBRAE criou o projeto Música Independente na Região Metropolitana de Belo Horizonte, que vem desenvolvendo alguns programas para capacitação do segmento, e foi responsável por demandar à FJP a realização do Diagnóstico da Cadeia Produtiva da Música em Belo Horizonte. Fonte: SEBRAE MG. Disponível em: http://www.sebraemg.com.br/Home/HomePortal.aspx. Acesso em: 10 Jun. 2010

${ }^{11}$ Criado em 1978, o grupo UAKTI emprega madeiras, bambus, pedras e água para produzir sons musicais. Sua trajetória confunde-se com a trajetória musical de Marco Antônio Guimarães, nascido em Belo Horizonte, em 1948. Violoncelista, compositor, arranjador e responsável pela criação do UAKTI (ao lado de Paulo Sérgio dos Santos, Décio de Souza Ramos Filho e Artur Andrés), sua direção musical e construção dos seus instrumentos não-convencionais. Fonte: Per Musi. Disponível em: http://www.musica.ufmg.br/permusi/port/numeros/23/num23 cap 17.pdf. Acesso em: 15 Jul. 2010.

${ }_{12}$ RedeSist é uma rede de pesquisa interdisciplinar do Instituto de Economia da Universidade Federal do Rio de Janeiro (UFRJ), criada em 1997, que conta com a participação de várias universidades e institutos de pesquisa no Brasil, além de manter parcerias com outras organizações internacionais. Fonte: site RedeSist. Disponível em: www.redesist.ie.ufri.br. Acesso em: 05 Mar. 2010.

${ }^{13}$ Integrante do Clube da Esquina, considerado por alguns críticos como "o maior guitarrista brasileiro vivo", cujo CD Harmonia e Vozes foi indicado ao $11^{\circ}$ Grammy Latino 2010 na categoria de melhor álbum de MPB. Fonte: Site Nova Cultura. Disponível em: http://novacultura.de/wb/pages/musica/o-som-do-brasil/toninhohorta.php 


\begin{abstract}
${ }^{14}$ Saxofonista, natural de Belo Horizonte - onde foi um dos fundadores do Berimbau Club, voltado para o Jazz, na década de 1950, e que se apresentou ao lado de nomes internacionais como Sarah Vaughan.

${ }^{15}$ Compositor e arranjador nascido no interior de Minas, mas cuja carreira foi desenvolvida a partir de Belo Horizonte. Possui discos lançados nos Estados Unidos, Canadá, Japão e Europa.

${ }^{16}$ Fonte: Relação Anual de Informações Sociais do Ministério do Trabalho e Emprego. Disponível em: http://portal.mte.gov.br/rais/resultados-definitivos.htm. Acesso: 12 Jun. 2010.

${ }_{17}$ Tadeu Martins Soares é poeta, instrumentista, compositor e produtor cultural, é atual diretor do Instituto Vale Mais - Instituto Sociocultural do Jequitinhonha.

${ }^{18}$ Graduado em Comunicação Social (Jornalismo), é cantor, ator e produtor cultural. Atualmente administra o Teatro Santo Agostinho e dirige a TW Comunicação e Arte, empresa de gestão e produção cultural.

${ }^{19}$ Formado pelas seguintes organizações: Serviço Nacional da Indústria (SENAI), Serviço Social da Indústria (SESI), Serviço Nacional de Aprendizagem Comercial (SENAC), Serviço Social do Comércio (SESC), Serviço Nacional de Aprendizagem Rural (SENAR), Serviço Nacional de Aprendizagem em Transportes (SENAT), Serviço Social do Transporte (SEST), Serviço Brasileiro de Apoio às Micro e Pequenas Empresas (SEBRAE), Serviço Nacional de Aprendizagem do Cooperativismo (SESCOOP). Fonte: SENAI. Disponível em: http://www.senai.br/br/ParaVoce/faq.aspx. Acesso em: 02. Fev. 2011

${ }^{20}$ Mestre, doutor e pós-doutor em Ciência Econômica, é estudioso de economia regional urbana e economia mineira, entre outros temas.

${ }^{21}$ A Sociedade Mineira de Software (FUMSOFT), com sede em Belo Horizonte, "atua na criação, capacitação, qualificação e fomento de empreendedores e organizações produtoras de software de Minas Gerais para o sucesso no mercado global". "São programas nas áreas de empreendedorismo, qualificação e certificação de produtoras de software, geração de negócios, pesquisa, desenvolvimento e inovação, trabalho cooperado, exportação, entre outras". Integra a Rede Softex - Associação para Promoção da Excelência do Software Brasileiro. Fonte: Site da FUMSOFT. Disponível em: http://e-
\end{abstract} portal.fumsoft.softex.br/fumsoft. Acesso em: 02. Fev. 2011

${ }^{22}$ A UFMG possui uma Diretoria de Ação Cultural, um Centro Cultural, um Conservatório, além das escolas de Música e de Belas Artes, responsáveis pela realização anual de centenas de espetáculos e atividades de música, dança, teatro e artes plásticas, a maioria aberta ao público. Realiza, há 42 anos, o Festival de Inverno, considerado "um dos mais importantes e tradicionais eventos culturais do país". Fonte: Site da UFMG. Disponível em: www.ufmg.br. Acesso em: 02 Mar. 2011.

${ }^{23}$ Doutor em História Econômica, professor do Centro de Desenvolvimento e Planejamento Regional da Faculdade de Ciências Econômicas da UFMG (Cedeplar).

${ }^{24}$ Fonte: Site da PUC-MG. Disponível em:

http://www.pucminas.br/ensino/mestrado doutorado/mestrado doutorado.php?\&pagina=947\&programa=13. Acesso em: 02 Mar. 2011.

${ }^{25}$ Violonista, compositor, arranjador, produtor musical, idealizador e coordenador do projeto Música de Minas.

${ }^{26}$ O Projeto Música Minas surgiu em 2008, quando representantes do segmento decidiram criar um plano de exportação e disseminação da música mineira a partir do então recém-criado Fórum da Música de Minas Gerais, que se torna o gestor oficial do programa. O projeto - voltado para compositores, intérpretes e instrumentistas de diversos gêneros e tendências musicais -, é apresentado à Secretaria de Estado de Cultura de Minas Gerais (SEC), que decide incentivá-lo, destinando-lhe orçamento de R $\$ 1,550$ milhão em 2009, distribuídos em duas categorias: a de Circulação Nacional de Artistas Mineiros e a de Passagens para Deslocamentos Nacionais e Internacionais. (MINAS GERAIS, 2009). Nos anos seguintes este valor foi sendo reduzido, chegando a $R \$ 1,15$ milhão em 2011.

27 Fonte: Site da SEC/MG. Disponível em: http://www.cultura.mg.gov.br/?task=interna\&sec=9\&cat=74. Acesso em: 02 Mar. 2011

${ }^{28}$ Parágrafo $1^{\circ}$ do Artigo $3^{\circ}$ da Lei oㅜ 12.343 de 02 dez. de 2010. (ANEXO II).

29 Fonte: Acordo de Cooperação Federativa do Sistema Nacional de Cultura. Disponível em: http://blogs.cultura.gov.br/snc/files/2010/12/GUIA-DE-ORIENTA\%C3\%87\%C3\%95ES-AOS-

MUNIC\%C3\%8DPIOS-SNC-PERGUNTAS-E-RESPOSTAS 19JAN2011.pdf. Acesso em: 02 Mar. 2011

${ }^{30}$ Graduada em Ciências Sociais e Antropologia, especialista em Políticas Culturais e Gestão Cultural. Atualmente, é parecerista do Ministério da Cultura (MinC) na área de Música e Humanidades e consultora do SEBRAE.

${ }^{31}$ Referência ao movimento musical Clube da Esquina. 


32 Fonte: Site da $\quad$ FMC.
http://portalpbh.pbh.gov.br/pbh/ecp/comunidade.do?evento=portlet\&pldPlc=ecpTaxonomiaMenuPortal\&app= fundacaocultura\&tax $=7664 \&$ lang $=p t$ BR\&pg=5520\&taxp=0\&. Aceso em: 03 Mar. 2011

${ }^{33}$ Belo Horizonte possui 208 comunidades, entre vilas, favelas, conjuntos habitacionais populares e outros assentamentos irregulares, totalizando 471 mil moradores ou 19,53\% da população da capital. Fonte: Site da Urbel/PBH. Disponível em:

http://portalpbh.pbh.gov.br/pbh/ecp/comunidade.do?evento=portlet\&pldPlc=ecpTaxonomiaMenuPortal\&app= urbel\&tax $=7491 \&$ lang $=$ pt br\&pg=5580\&taxp=0\&

${ }^{34}$ Ribeirão das Neves (Norte e Noroeste), Santa Luzia (Norte e Nordeste), Sabará (Lste), Nova Lima (Sul e Sudeste), Ibirité (Sudoeste) e Contagem (Noroeste e Oeste). Fonte: Portal Brasil. Disponível em: http://www.portalbrasil.net/brasil cidades bh.htm. Acesso em: 15 Mar. 2011.

35 Fonte: PBH/Contas Públicas/Execução orçamentária/Demonstrativos e Relatórios. Disponível em: http://migre.me/41Wuv. Acesso em: 23 Mar. 2011.

36 "O nome do teatro é uma homenagem ao grande clarinetista e maestro mineiro Francisco Nunes (18751934), que criou a Sociedade de Concertos Sinfônicos de Belo Horizonte e dirigiu o Conservatório Mineiro de Música". Fonte: Site PBH. Disponível em:

http://portalpbh.pbh.gov.br/pbh/ecp/contents.do?evento=conteudo\&idConteudo=25459\&chPlc=25459\&termo $\mathrm{s}=$ hist $\tilde{A}^{3}$ ria do teatro Francisco Nunes.

37 "A MEC AM, voltada para a Música Popular Brasileira, apresenta programas variados que contemplam, ainda, música regional, bossa-nova, jazz e música instrumental. [...] A MEC FM transmite música de concerto em $90 \%$ de sua programação, com janelas de jazz, choro e música instrumental. [...] Com uma história que se confunde com a própria história do país nos últimos 70 anos, a Rádio MEC possui, hoje, um dos mais importantes acervos do rádio brasileiro, com quase 50 mil fitas de gravações e programas temáticos". Fonte: Site Rádio MEC. Disponível em: http://www.radiomec.com.br/70anos/intro.htm. Acesso em: 20 Mar. 2011.

${ }^{38}$ Fonte: IBGE. Disponível em:

http://www.ibge.gov.br/home/presidencia/noticias/noticia visualiza.php?id noticia=1766.

Acesso em: 17 Mar. 2011.

39 Fonte: IBGE. Disponível em:

http://www.ibge.gov.br/home/presidencia/noticias/noticia visualiza.php?id noticia=1766. Acesso em: 17 Mar. 2011.

40 Alguns exemplos: a implantação do Parque Tecnológico de Belo Horizonte (BHTec), o Centro de Pesquisa e Desenvolvimento do Google para a América Latina e o Centro de Exposições Expominas.

${ }^{41}$ Quando o indivíduo se desloca visando desenvolver empreendimentos com fins lucrativos, através de reuniões de negócios, a fim de fechar acordos, comprar produtos ou serviços ou acertar outras questões pontuais relacionadas à atividade de mercado. Envolve setores como transporte, hospedagem, alimentação e lazer.

42 Fonte: Site do FOHB. Projeção da taxa de ocupação nas 12 cidades-sede da Copa do Mundo no Brasil. Disponível em: http://www.asacom.com.br/hvs/FOHB 2010. Acesso em: 10 Fev. 2011.

Jane Maria de Medeiros é jornalista e produtora cultural, especialista em Gestão Estratégica Cultural e Mestre em Gestão Social, Educação e Desenvolvimento Local. Durante dez anos, exerceu o cargo de Coordenadora de Projetos Culturais do Conservatório UFMG. Atualmente, presta assessoria à diretoria da Escola de Música da UFMG na concepção e produção de projetos institucionais. Foi membro do Conselho Administrativo do Instituto Cultural Sérgio Magnani (2006/2011), tendo sido sua primeira presidente (2004/2005). Uma das fundadoras do Fórum dos Dirigentes das Casas de Espetáculos de Minas Gerais, integrou a sua diretoria nas gestões 2004/2007 e 2008/2011. Integra a Rede de Empreendedores Culturais (ReCult) e o Grupo de Trabalho da Cultura do Movimento Nossa BH, criado em 2008. Foi uma das idealizadoras do 
Fórum pela Cultura de Minas, criado em 2010. É membro, eleita, do Núcleo de Articulação Política do Fórum da Música de Minas Gerais para o biênio 2012/2013.

Lucília Regina de Souza Machado é Coordenadora do Mestrado em Gestão Social, Educação e Desenvolvimento Local do Centro Universitário UNA (Belo Horizonte, MG), Professora Titular aposentada da Faculdade de Educação da Universidade Federal de Minas Gerais, Doutora em Educação, Pós-Doutora em Sociologia do Trabalho, Mestre em Educação e Graduada em Ciências Sociais. Membro da Comissão Assessora de Expertos Ibero-americanos em Educação Técnico Profissional da Organização dos Estados Iberoamericanos (OEI). Membro da Comissão Executiva Nacional de Cursos Técnicos de Nível Médio (Conac) da Secretaria de Educação Profissional e Tecnológica do Ministério da Educação. 